\title{
Growth and distribution after the 2007-2008 US financial crisis: who shouldered the burden of the crisis?
}

\author{
Mathieu Dufour* \\ Département des Sciences Sociales, Université du Québec en Outaouais, Gatineau, QC, Canada \\ Özgür Orhangazi** \\ Department of Economics, Kadir Has University, Istanbul, Turkey
}

The post-1980 era witnessed an increase in the frequency and severity of financial crises around the globe, the majority of which took place in low-and middle-income countries. Studies of the impacts of these crises have identified three broad sets of consequences. First, the burden of crises falls disproportionately on labor in general and low-income segments of society in particular. In the years following financial crises, wages and labor share of income fall, the rate of unemployment increases, the power of labor and labor unions is eroded, and income inequality and rates of poverty increase. Capital as a whole, on the other hand, usually recovers quickly and most of the time gains more ground. Second, the consequences of crises are visible not only through asset and income distribution, but also in government policies. Government policies in most cases favor capital, especially financial capital, at the expense of large masses. In addition, many crises have presented opportunities for further deregulation and liberalization, not only in financial markets but in the rest of the economy as well. Third, in the aftermath of financial crises in low-and middle-income economies, capital inflows may increase as international capital seeks to take advantage of the crisis and acquire domestic financial and non-financial assets. The 2007-2008 financial crisis in the US provides an opportunity to extend this analysis to a leading high-income country and see if the patterns visible in other crises are also visible in this case. Using the questions and issues typically raised in examinations of low-and middle-income countries, we study the consequences of the 2007-2008 US financial crisis and complement the budding literature on the 'Great Recession.' In particular, we examine the impacts of the crisis on labor and capital, with a focus on distributional effects of the crisis such as changes in income shares of labor and capital, and the evolution of inequality and poverty. We also analyse the role of government policies through a study of government taxation and spending policies, and examine capital flow patterns.

Keywords: financial crisis, Great Recession, 2008 crisis

JEL codes: $G 01, D 31, E 62, F 21$

* Email: mathieu.perron-dufour@uqo.ca.

** Corresponding author - Email: ozgur.orhangazi@khas.edu.tr. 


\section{INTRODUCTION}

The post-1980 era witnessed an increase in the frequency and severity of financial crises around the globe (Eichengreen 2001; Reinhart and Rogoff 2011). Apart from the large amount of literature that examines the causes of these crises, another line of research has concerned itself with the consequences of financial crises. Three broad findings emerge from the latter, which focuses on low- and middle-income country experiences, as this is where most of the major financial crises have taken place in the last couple of decades. First, the burden of crises falls disproportionately on labor in general and low-income segments of society in particular. In the years following financial crises, wages and labor share of income fall, the rate of unemployment increases, the power of labor and labor unions is eroded, and income inequality and rates of poverty increase (Diwan 2000; 2001; Jayadev 2005; Onaran 2007). Capital as a whole, on the other hand, usually recovers quickly and most of the time gains more ground. Second, the consequences of crises are visible not only through asset and income distribution, but also in government policies. Government policies in most cases favor capital, especially financial capital, at the expense of the rest of society. In addition, many crises have presented opportunities for further deregulation and liberalization, not only in financial markets but in the rest of the economy as well (Crotty and Lee 2001; Harvey 2003; Duménil and Lévy 2006; Dufour and Orhangazi 2007; 2009). Third, in the aftermath of financial crises in low- and middleincome economies, capital inflows often increase as international capital seeks to take advantage of the crisis and acquire domestic financial and non-financial assets (Wade and Veneroso 1998; Dufour and Orhangazi 2007; 2009).

The 2007-2008 financial crisis in the US provides an opportunity to extend this analysis to a leading high-income country and see if the patterns visible in other crises are also visible in this case. Using the questions and issues typically raised in examinations of low- and middle-income countries as an entry point to look at the experience of the US economy in the aftermath of the 2007-2008 financial crisis provides a fresh perspective on that crisis and allows for an original contribution to the gradually emerging literature on the consequences of the US financial crisis and the 'Great Recession' (for example, Oleinik 2013; Wolff 2013). In this paper, we empirically investigate the outcome using broad indicators such as changes in inequality and poverty, and then compare the fortunes of labor and capital after the crisis. We find that unemployment has substantially increased and labor incomes have fallen, but the income share of capital and profitability continued to increase after the crisis. While the US did not need an external bailout, such as those the IMF provided during earlier financial crises in less-developed countries, the US government and the Federal Reserve (FED) provided unprecedented amounts of support to the economy. Since they were not constrained by an external structural adjustment program and since the FED has the power to issue an international reserve currency, the outcomes of the crisis in this regard differed from other experiences. However, capital inflows peaked during the crisis, suggesting that it opened business opportunities for international capital in similar ways as previous crises did.

The rest of the paper is organized as follows. In Section 2 we look at the emergence of the 2007-2008 US financial crisis and the path of some important macroeconomic indicators before and after the crisis. In Section 3 we turn our attention to the distributional effects of the US financial crisis and then compare this with the impacts of the crisis on capital. We compare the changes in income shares of labor and capital before shifting our attention to changes in inequality and poverty. Section 4 focuses 
on the role of government policies through an analysis of government taxation and spending policies. After discussing the change in capital flows in Section 5, we conclude in Section 6 with a discussion of our overall findings and further research areas.

\section{MACROECONOMICS OF THE CRISIS}

The last three decades have been characterized by an increase in the power of capital over labor in the US. During this period, wages declined or stagnated despite increasing productivity (Mishel 2012; Mishel and Gee 2012), and income and wealth inequality rose (Piketty and Saez 2006; Duménil and Lévy 2011). ${ }^{1}$ Meanwhile, the US economy became more financialized, which not only led to a further redistribution of income to finance capital, but also to an increase in financial fragility, culminating in the financial crisis of 2007-2008 (Orhangazi 2008; 2011). The precise beginning of the financial crisis is difficult to determine. The number of mortgage delinquencies began to rise in early 2007 and led to bankruptcies among subprime mortgage lenders. The FED, along with the world's major central banks, perceived the problem as one of liquidity and around the summer of 2007 began injecting liquidity into world financial markets. However, in March 2008, Bear Stearns, one of the largest investment banks, almost collapsed and was acquired by JP Morgan Chase with the backing of the FED. This event made it clear that there was a major financial crisis at hand which was not limited to the subprime mortgage market. Four months later, the Federal Deposit Insurance Corporation (FDIC) had to take over IndyMac Bank. The crisis accelerated in September with the takeover of Fannie Mae and Freddie Mac, the near collapse of Merrill Lynch - acquired by Bank of America - and the bankruptcy of Lehman Brothers, along with the bailout of AIG, all happening within a month. According to the National Bureau of Economic Research (NBER), the US economy entered into a recession around December 2007 and the recession ended in June 2009. ${ }^{2}$ Table 1 shows some important economic indicators before, during, and after the financial crisis and the recession.

The data show that this is one of the most serious downturns for the US economy historically and that the recovery has been quite limited. The annual growth performance of the economy remains well below the precrisis era to this day. While non-residential investment has slowly inched back up towards precrisis levels, residential investment is still near rock bottom at 2.6 percent of GDP at the end of 2012, down from 5-6 percent before the subprime trouble started. With government spending measures phasing out and further cuts imposed as a result of budget negotiations and the effective federal funds rate already as low as it can be, it is not clear whether investment will pick up in future quarters. While the share of personal consumption in the GDP remained quite high, overall its quarterly increases are still below precrisis levels. The trade deficit, however, shrank towards the end of the crisis and has remained lower than precrisis levels since then. This macro picture is not exactly rosy, but some sectors and groups in society have fared worse than others in spite, or perhaps because, of the

1. There is a debate regarding the proper measures of productivity and workers' compensation and thus of the size of the disconnection between the two (for example, Feldstein 2008). Nonetheless, even when factors such as price deflators or inequality are set aside, a sizeable disconnection remains (Pessoa and Van Reenen 2012).

2. The NBER defines a recession as 'a significant decline in economic activity spread across the economy, lasting more than a few months, normally visible in real GDP, real income, employment, industrial production, and wholesale-retail sales' (http://www.nber.org/cycles.html). 


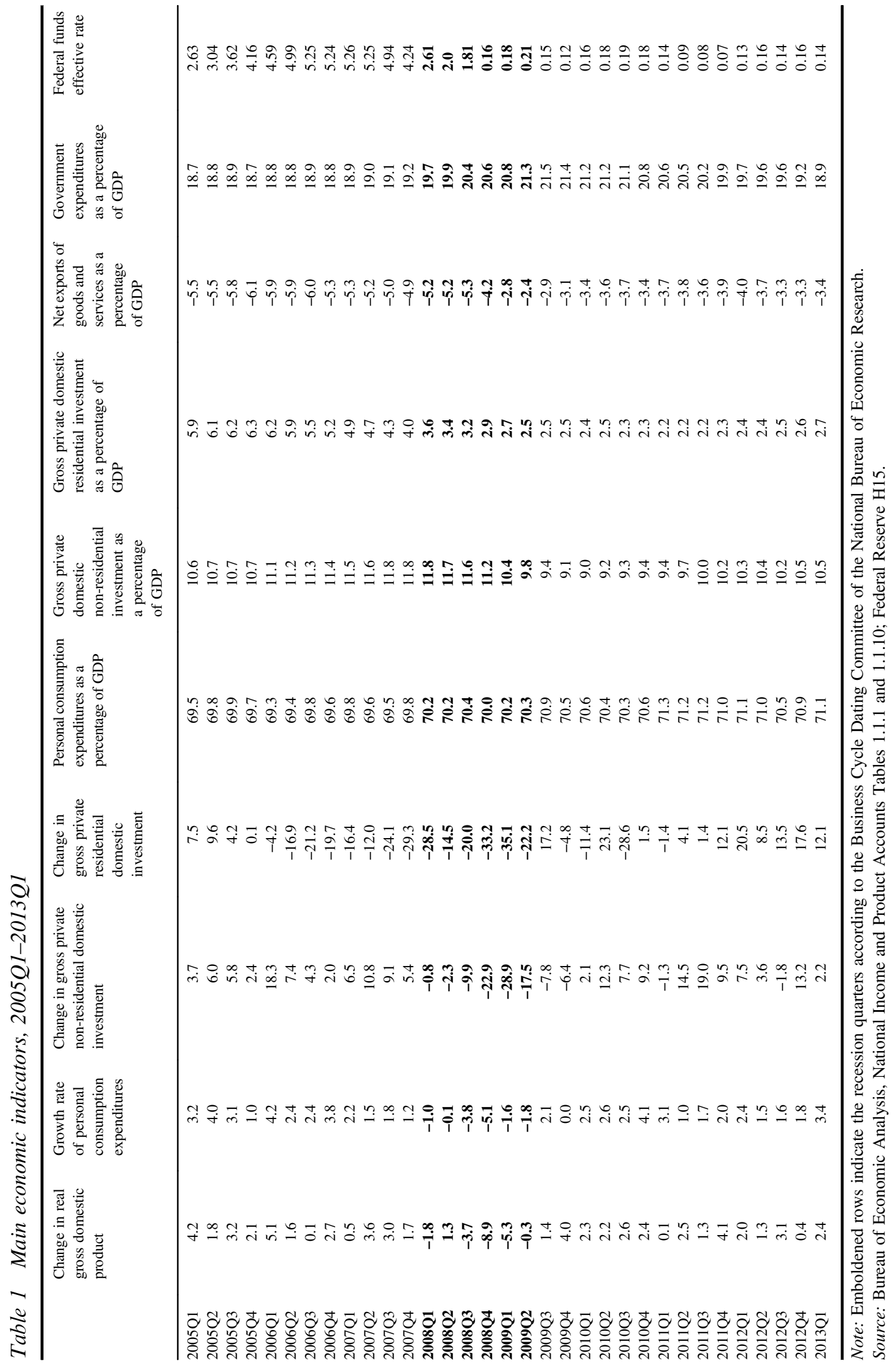


vast government resources that were committed to the recovery. In the following sections we analyse in detail how different groups were hit by the crisis and the extent to which their fortunes have improved after the financial crisis.

\section{CRISIS AND DISTRIBUTION}

\subsection{Unemployment and wages}

To understand the consequences of a financial crisis, it is crucial to ascertain how the burden was distributed in society. Labor is a useful starting point for such an undertaking as crises typically result in increased rates of unemployment and a decrease in pay and benefits. The power of labor can also be affected in different ways if, for example, the crisis is used as a pretext for labor repression, or resistance to different measures and outcomes energizes it. Figure 1 shows two measures of the rate of unemployment: the official rate and a broader measure (labeled 'U6'), which includes marginally attached workers, such as discouraged workers and individuals working part-time for economic reasons. The rate of unemployment, which was below 5 percent right before the US crisis, reached almost 10 percent at its peak. It has since begun to come down, but was still recorded at 7.3 percent in October 2013 (Federal Reserve Bank of St. Louis). If we include unwilling part-time workers and individuals marginally attached to the labor market, the rate started a little above 8 percent before the crisis and peaked at 17.1 percent. It has also since come down, but relatively more slowly,

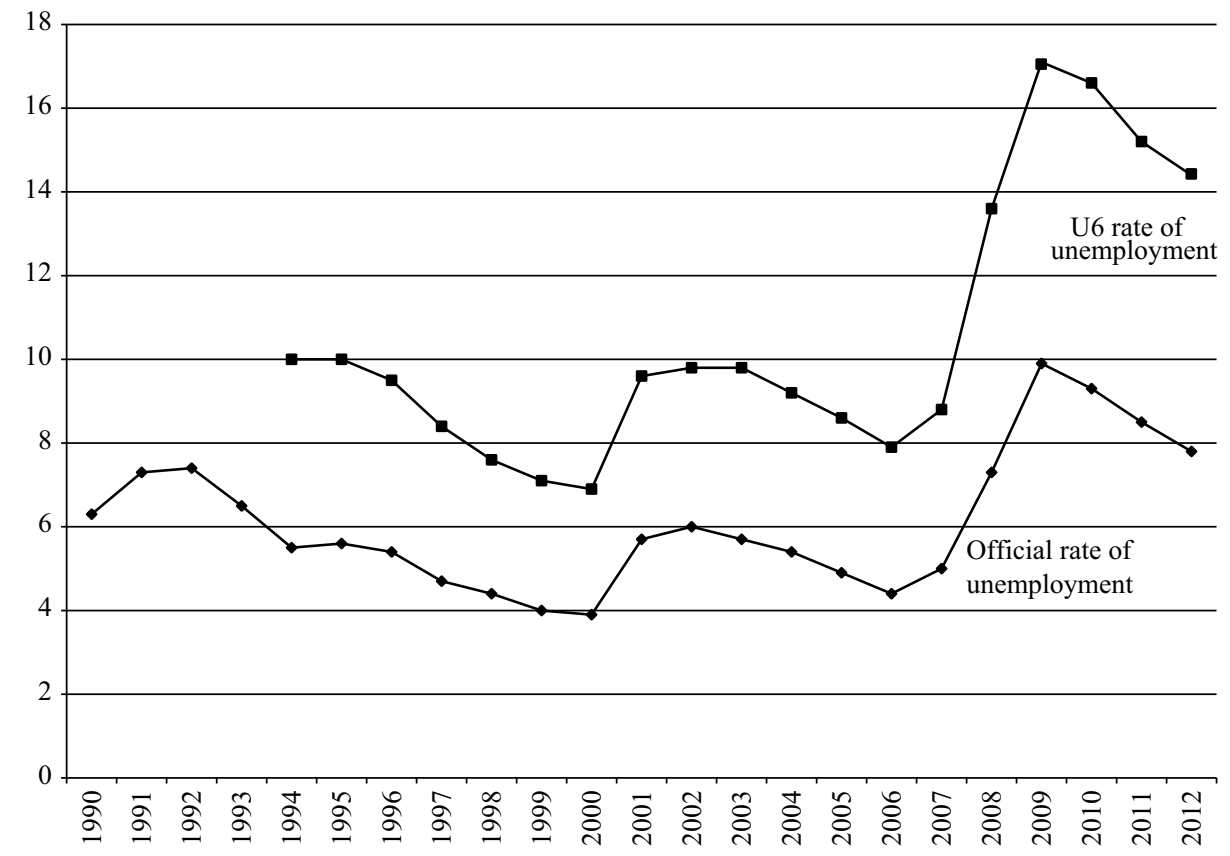

Source: FRED.

Figure 1 The rate of unemployment (\%) 
hovering around 14 percent for most of 2013 (Federal Reserve Bank of St. Louis). This suggests that while some people are finding work, many remain underemployed or simply discouraged by their job prospects.

A look at the labor force participation rate and the proportion of the civilian population that is employed reinforces that assessment (Figure 2). The labor force participation rate, which stood above 66 percent before the US crisis, has been dropping since 2007 and stood at 63.6 percent at the end of 2012, going down to 62.8 percent by October 2013 (Federal Reserve Bank of St. Louis). The evolution of the rate of employment is even starker: from around 63 percent before the crisis, it had decreased to 58.3 percent by October 2013 (Federal Reserve Bank of St. Louis), with virtually all the drop happening in 2008 and 2009. Both rates are now at their lowest since the early 1980s and show no sign of going back up. Overall, those indices offer a picture of a stagnant labor market from which many workers simply choose to exit, while many others have to make do with part-time employment.

Furthermore, there is a polarization of the workforce. Most of the employment losses since 2007 occurred in mid-wage occupations, but the jobs created afterwards have been concentrated in lower-wage occupations. Lower-wage occupations grew 2.7 times faster than mid- and high-wage jobs. According to a study by the National Employment Law Project (2012), during the recession 21 percent of the job losses were in lower-wage occupations while 58 percent of jobs created during the recovery were low-wage jobs. 60 percent of the jobs lost were in mid-wage occupations and only 22 percent of the jobs created were mid-wage jobs. And 19 percent of the losses were composed of higher-wage occupations and these represented 20 percent of the

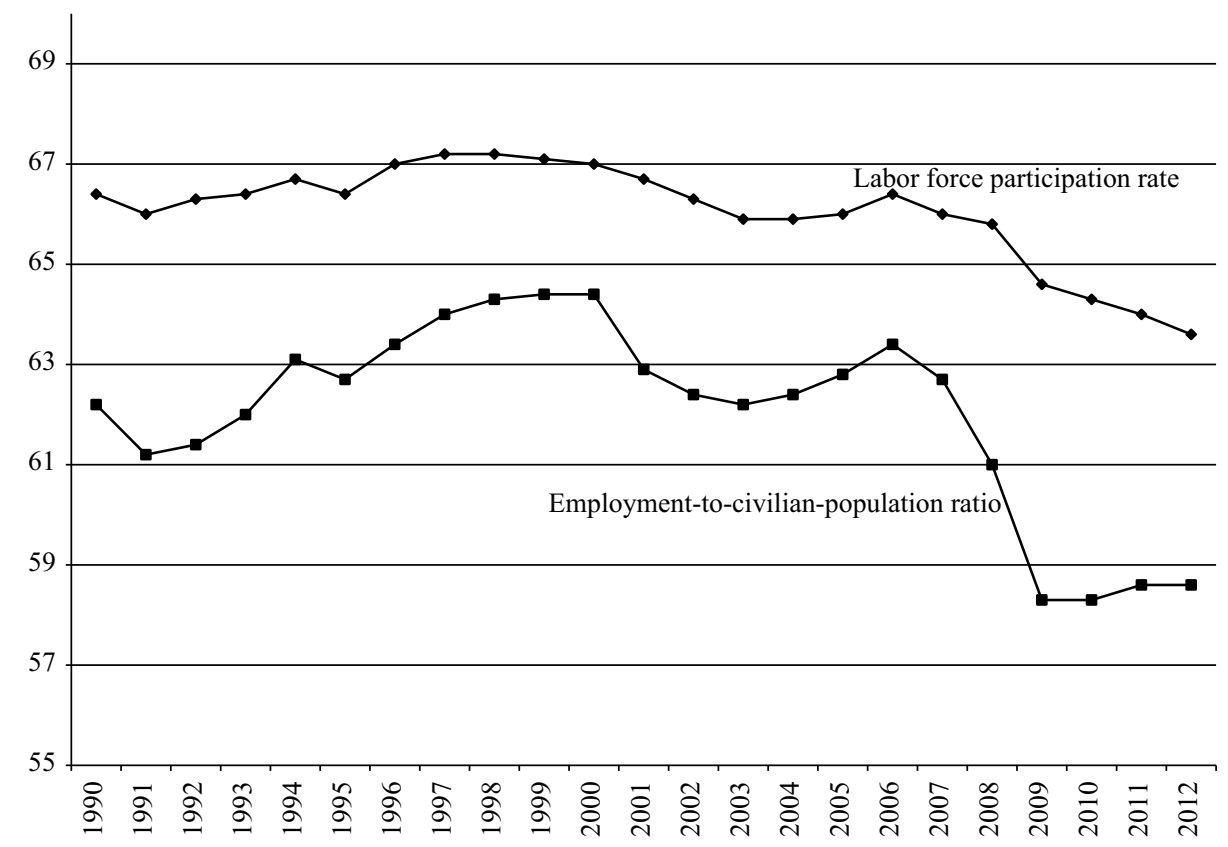

Source: FRED.

Figure 2 Labor force participation rate and employment-to-civilian-population ratio (\%) 
recovery. The same report suggests that these results are due both to the fact that lowwage industries, such as food services or retail, are experiencing relatively high job growth, but also that jobs are not being created in mid-wage occupations in other industries. As a result, the proportion of workers earning wages below poverty-level increased from 23.3 percent in 2006 to 28 percent in 2011. Similarly, the proportion of men working at or below minimum wage went from 2.5 percent in 2006 to 4.2 percent in 2009 , while 4.1 percent of women worked at or below minimum wage in 2006 compared to 6.2 percent in 2009 (Mishel et al. 2012, ch. 4). Table 2 shows the percentage change in real annual wages after 2007 by wage group. We observe that while the top 1 percent experienced a large decline in real wages immediately after the US crisis, the recovery has been strong, though not enough to offset the losses. The 95-99 percentile, on the other hand, rapidly recovered its real wage losses after the crisis. However, for the bottom 90 percent, the change in percentage in real annual wages was negative from 2007 to 2011.

Like employment, labor income has also dropped since the beginning of the US crisis. After being stagnant for over two decades, the real median hourly wage increased by a couple of 2011 dollars in the mid 1990s and stabilized at a new plateau in the early 2000 s, though there was a slight decrease near the middle of the decade (Figure 3 ). The same pattern is apparent in median total compensation, a broader income measure that includes benefits. Strangely, both measures of income slightly increase early on in the crisis before heading down again. Upon closer examination, this seems to be the result of the slight deflation in 2009. We can suppose that wage contracts, typically negotiated in nominal terms, had a built-in inflation expectation and that one year of deflation thus boosted real incomes. In fact, if we simply impute the precrisis average rate of inflation ${ }^{3}$ to 2009 , we get a decrease in median wage and total compensation for that year as well; there would have been a loss of about one dollar in real income (wages or total compensation). Thanks to the deflation in 2009, however, by 2011 wages were only $\$ 0.33$ below their 2007 level and total compensation was virtually at the same level. Still, even that smaller decrease was enough to send the median wage back to its 1999-2000 level.

The loss of income does not seem to have been uniform across income groups. Comparing average and median total compensation (Figure 3), it can be seen that not only did the average not stagnate from the mid 1970s onward, but the drop following the crisis was relatively small. The drop would have been larger for average total

\section{Table 2 Percentage change in real annual wages after the financial} crisis

\begin{tabular}{lcccc}
\hline & \multicolumn{4}{c}{ Wage group } \\
\cline { 2 - 5 } & Top 1.0\% & $95-99 \%$ & $90-95 \%$ & Bottom 90\% \\
\hline $2007-2009$ & $-15.60 \%$ & $-1.10 \%$ & $1.00 \%$ & $-0.60 \%$ \\
$2009-2011$ & 8.2 & 2.1 & 0.6 & -1.2 \\
$2007-2011$ & -8.6 & 1 & 1.6 & -1.8 \\
\hline
\end{tabular}

Source: Mishel and Finio (2013), table 1.

3. We use the average inflation rate from 2000 to 2007 , which was 2.73 percent for the price deflator used on the income series. 


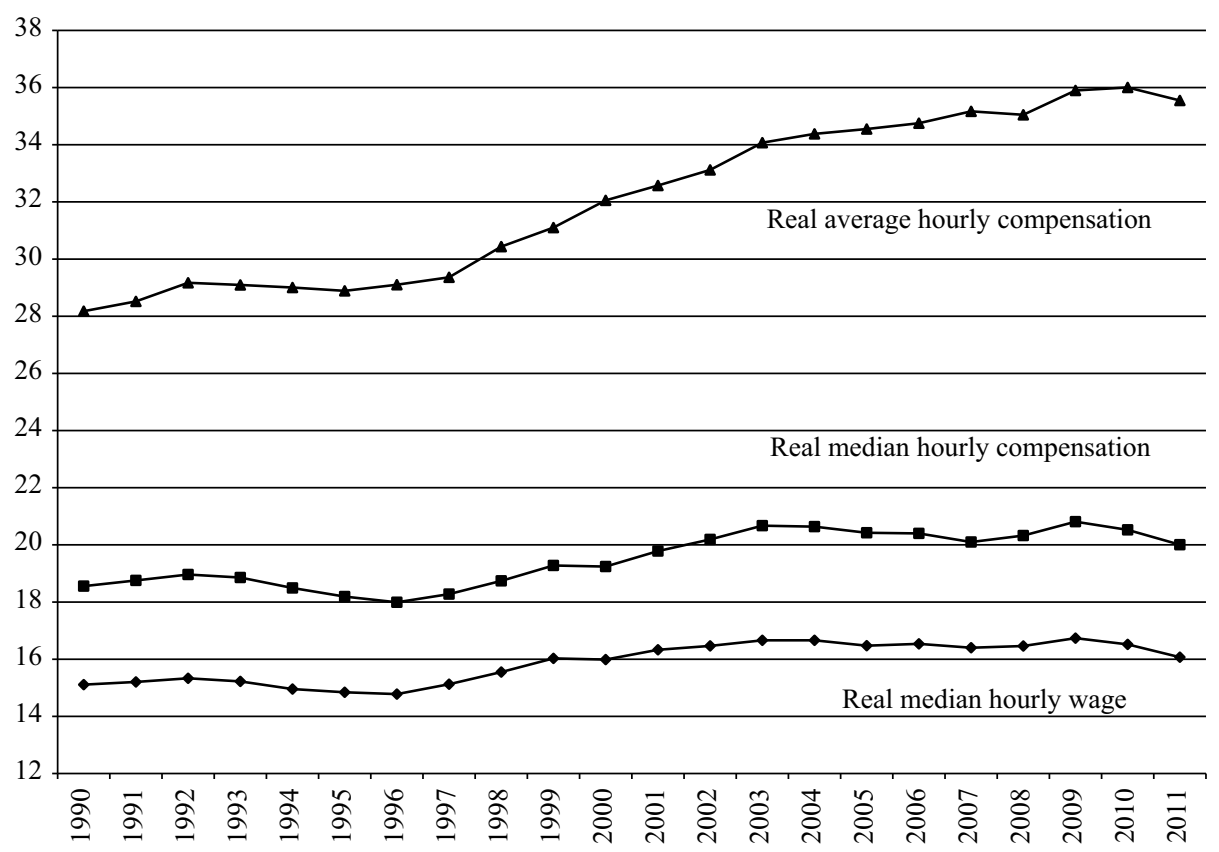

Source: Mishel and Gee (2012).

Figure 3 Real median hourly wage and hourly compensation vs average hourly compensation (2011 dollars)

compensation without the deflation in 2009, but it would have set it back to 2005 levels instead of the beginning of the decade like the median total compensation. ${ }^{4}$

Lastly, we examine whether or not there was a change in the bargaining power of labor after the financial crisis. Unionization rates and data on work stoppages can proxy for this. Union membership has been quite low in the US for some time. From rates around 22-24 percent during the 1970s, union membership among wage and salary workers had been experiencing a secular decline, and by the mid 2000s it had stabilized at 12-12.5 percent (Figure 4). The crisis gave it a little nudge downward, and by 2012 membership was down to 11.2 percent. Most of the drop happened after 2009, suggesting that union jobs were lost in the crisis and non-union jobs were created in the recovery. The picture is even starker if we focus on the private sector. In the 1970s, 21-24 percent of the sector was unionized, but by 2008 union membership was a mere 7.6 percent. The percentage decreased to 6.6 percent by 2012 .

The figures above are not surprising. In the US, workers lost a lot of power in the post-1980 era. When we look at worker militancy proxied by work stoppages or the proportion of work time spent idle due to work stoppages, we see that little has been happening since the early 1980s (Figure 5). In that respect, the neoliberal era stands in stark contrast to the previous period: there is no gradual decline akin to

4. These statistics are for all workers. For evidence on the differential impact of the financial crisis on race and gender, see for example Peterson (2012), Arestis et al. (2013) and Dymski et al. (2013). 


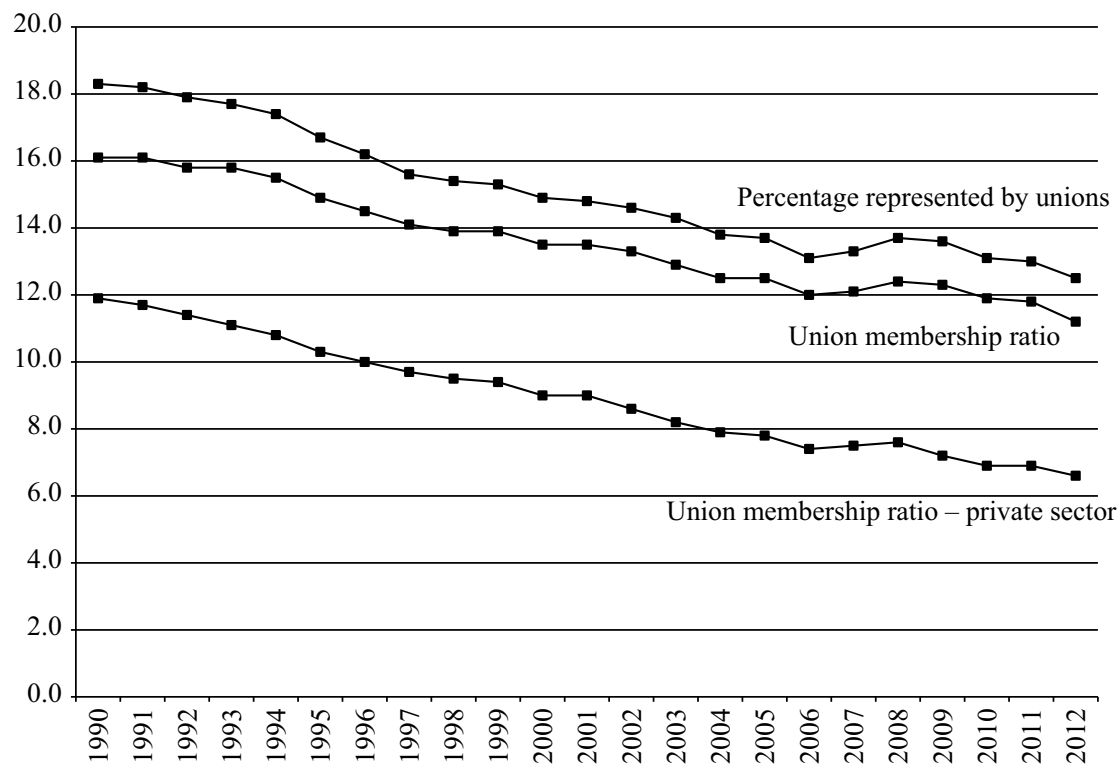

Source: unionstat.com, property of Barry T. Hirsh and David A. Macpherson.

Figure 4 Union membership and percentage represented by unions

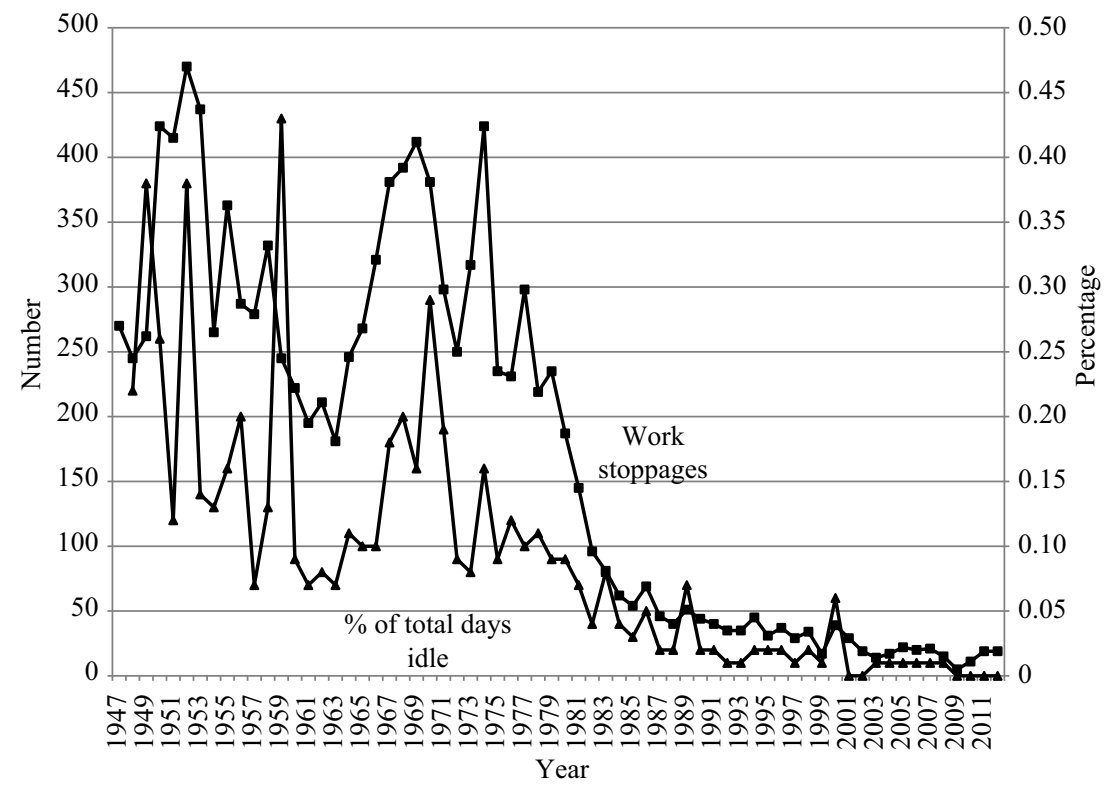

Note: The axis on the left represents the number of work conflicts, while the axis on the right is for the percentage of total workdays spent idle as a result of these conflicts.

Source: Bureau of Labor Statistics.

\section{Figure 5 Worker militancy}


that of union membership but, rather, a steep drop between the 1970s and the 1980s. Union activity and work stoppages were already at a minimum in the US before the crisis, which itself does not seem to have changed this situation. This lack of power may explain the losses of labor.

In short, labor in general suffered after the financial crisis both in terms of declining employment opportunities and declining wages. The rate of unemployment reached new heights, which is most visible in the U6 rate of unemployment. Even though it seems to have come down from its peak, the broader measure of employment-tocivilian-population ratio shows a significant decline since the crisis, suggesting that most of the gains in unemployment came from people leaving the labor force. Within labor, it appears that the bottom 90 percent suffered the most. The bargaining power of labor has declined as well. In terms of the power of labor, one indicator - the rate of unionization, which was already at pretty low levels - further declined. Let's now take a look at the overall distribution of income between labor and capital.

\subsection{Labor vs capital}

The labor share of income, measured as total labor compensation as a percentage of GDP, illustrates the overall situation of labor after the crisis (Figure 6). This labor share of income shows a slight increase in the crisis year of 2008 and then starts falling. The same trend is observed within the corporate sector as well. Figure 7 shows the compensation of employees as a share of corporate gross value added. In the years of the financial crisis, the long-term decline in this ratio is reversed temporarily but it starts falling again to reach a new low. While labor is seeing its share of income dwindle even further as a result of the crisis, profits have fared much better. Figure 7 also depicts the share of after-tax profits within the gross value added of the corporate sector. After briefly declining in the crisis years of 2007 and 2008, this ratio reached

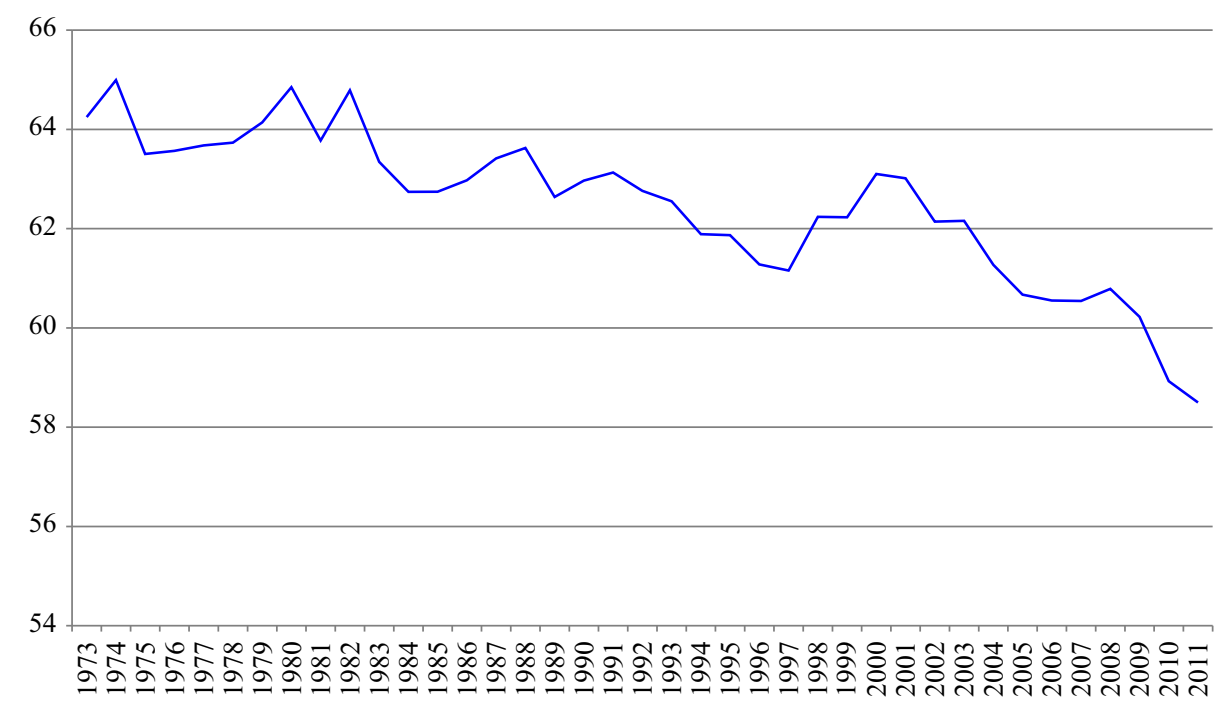

Source: Bureau of Economic Analysis.

Figure 6 Total labor compensation as a percentage of GDP 


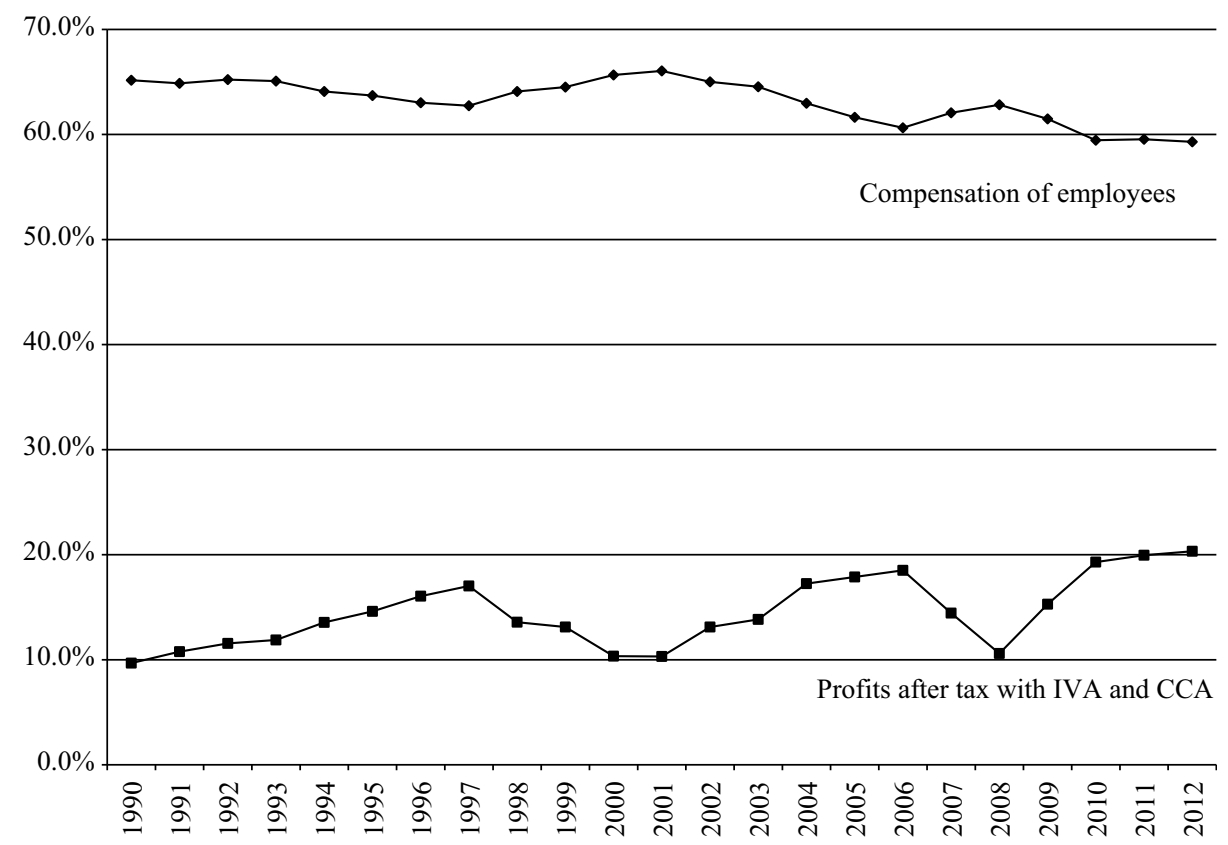

Source: Bureau of Economic Analysis.

\section{Figure 7 Income shares within gross value added of corporate sector}

historical heights a few years after the crisis. After experiencing a steep - but very short-lived - decline during the third quarter of 2008, in the midst of the crisis, after-tax profits as a share of GDP rose again and are now at their highest level since the Second World War.

The compensation of CEOs did not quite recover as quickly, though it remains at historically high levels. Two indices of the ratio of CEO-to-worker compensation developed by the Economic Policy Institute (EPI), options granted and options realized, indicate that while there was a drop in that ratio during the crisis, and especially in 2009, it remains above mid-1990s levels (Figure 8). ${ }^{5}$

Figure 9 shows the after-tax profits of the non-financial corporate sector as a percentage of their non-financial assets. This ratio begins declining in 2007 as the economy slides into a recession. Soon after, though, non-financial corporations' profitability not only recovers but surpasses precrisis levels. This is consistent with the initial drop in the profit share of corporate income (see Figure 7).

Figure 10 shows the banking sector's net income as a percentage of its total assets. The profitability of the banking sector took a dive with the financial crisis. As a result of the financial crisis there has been a significant redistribution and concentration

5. 'Options realized' include salary, bonuses, restricted stock grants, long-term incentive payouts, and options exercised, while 'options granted' include the same categories, with options granted instead of realized. The measures include the CEOs of the 350 largest firms by sales. The wage measure is the hourly wage of a typical non-supervisory/production worker in the relevant industry. For a more complete discussion of the methodology used by the EPI, see Mishel and Sabadish (2002). 
162 Review of Keynesian Economics, Vol. 4 No. 2

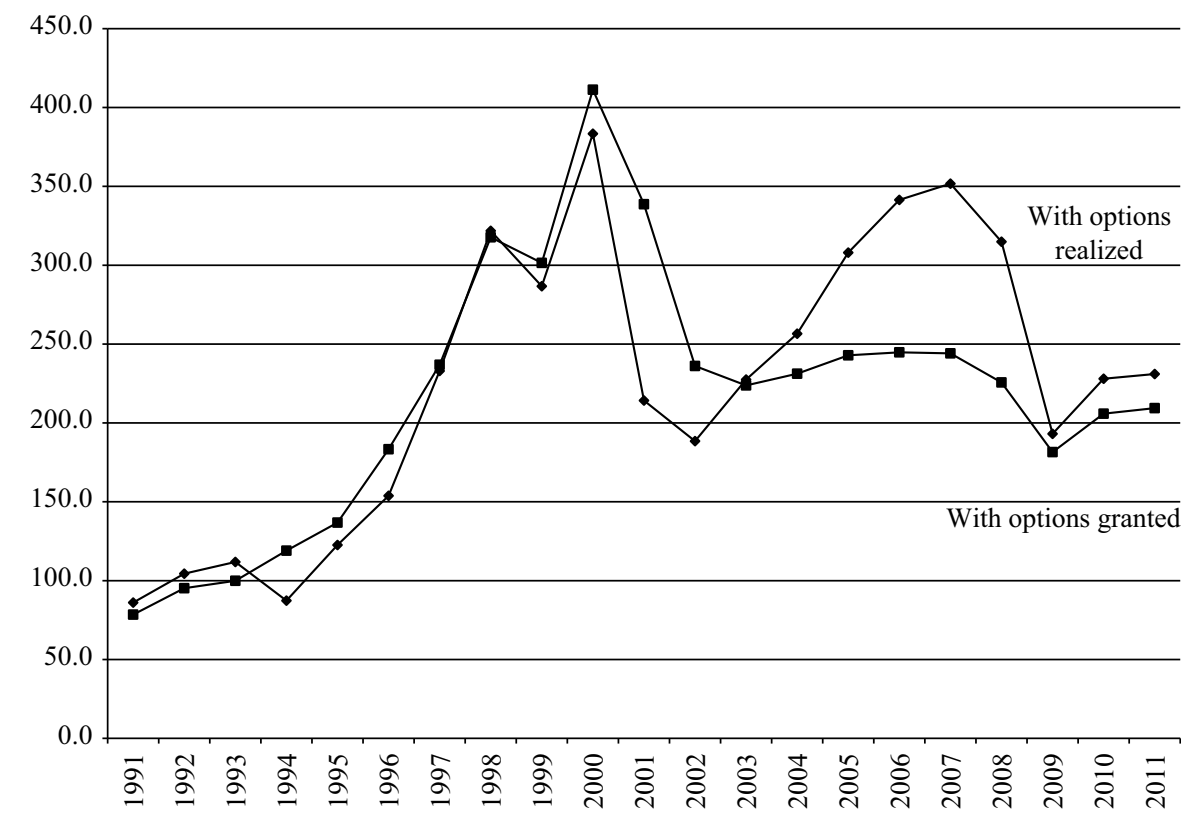

Source: Economic Policy Institute.

Figure 8 CEO-to-worker compensation ratio

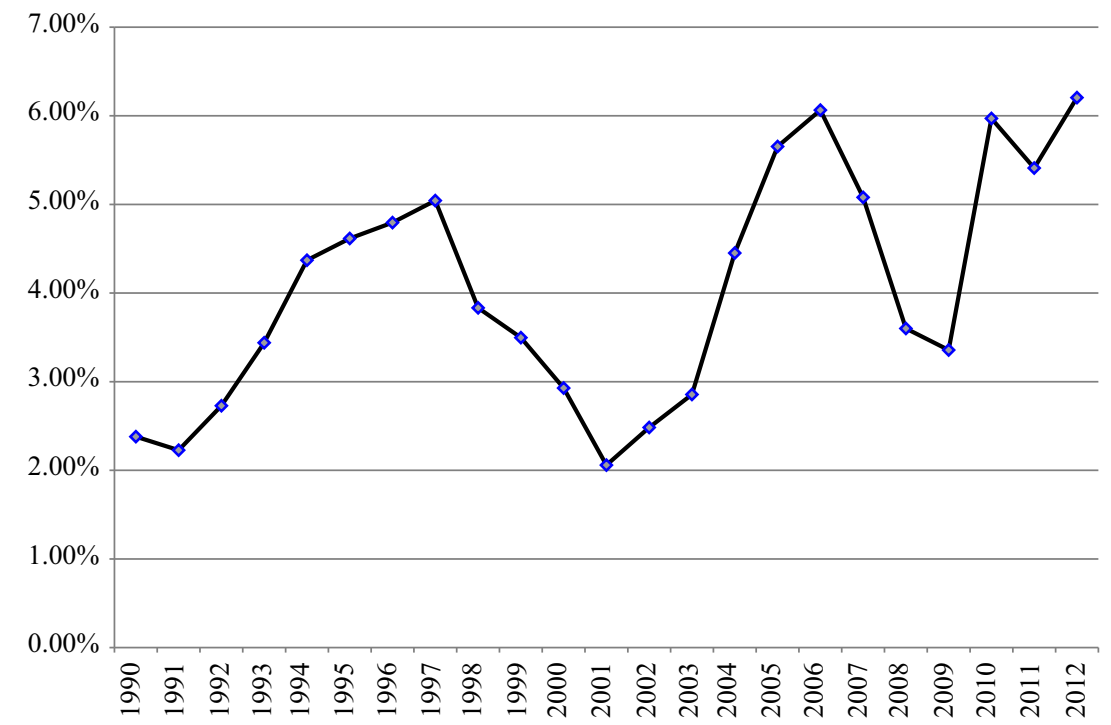

Source: Flow of Funds Accounts of the US.

Figure 9 NFC after-tax profits as a percentage of non-financial assets 


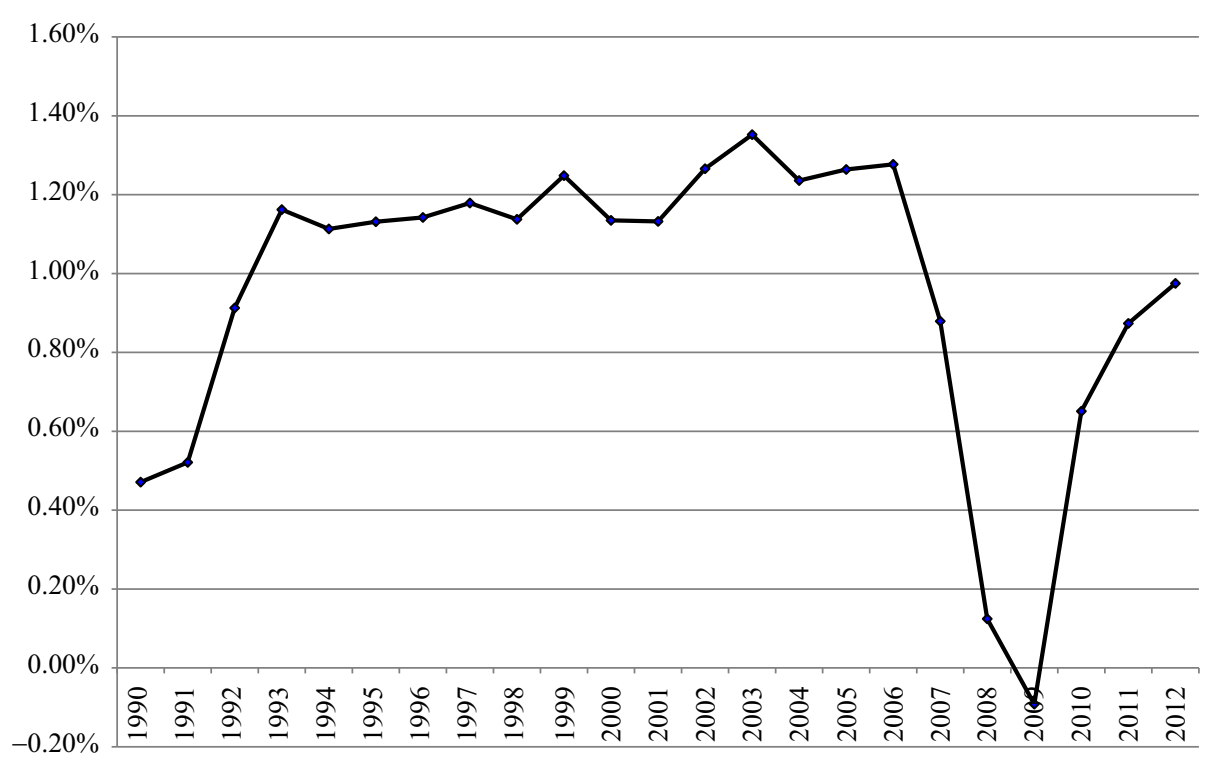

Source: FDIC.

Figure 10 Banking sector net income as a percentage of total assets

of wealth and power within the financial sector. Bank of America, Citigroup, and JP Morgan Chase all increased their size and market share through acquisitions and other means. The government's strategy of consolidating failing financial institutions resulted in the creation of mega financial institutions. In the following years there was a strong recovery in the profitability of the banking sector.

In short, labor's share both within gross domestic product as well as within the corporate sector fell a couple of years after the crisis. If one takes the CEO-to-worker compensation ratio as another indicator, it is clear that overall capital seems to be faring better than labor in the recovery so far.

\subsection{Income inequality}

Income inequality in the US has been increasing since the 1970s. The initial relative decrease in the CEO-to-worker compensation ratio in the midst of the crisis is illustrative of a broader temporary downward trend in income inequality. For example, the Gini coefficient, which had been increasing during the previous decades, decreased slightly in 2007 and 2008 before resuming its upward trend and reaching its highest level in 2011 (Figure 11). Similarly, the share of income going to the top quintile dropped slightly, early in the crisis, but then resumed its upward movement (Figure 12). Conversely, the share of the second and third quintiles rose slightly during the crisis, but then resumed the downward trend they had been experiencing in the last three decades, while the fourth and fifth quintiles basically continued to decrease (Figure 13). Interestingly, there have been some fluctuations at the top percentiles of income distribution. While the income share of the top 1 percent declined during the crisis, the share of the 90th to the 99th percentiles actually 
164 Review of Keynesian Economics, Vol. 4 No. 2

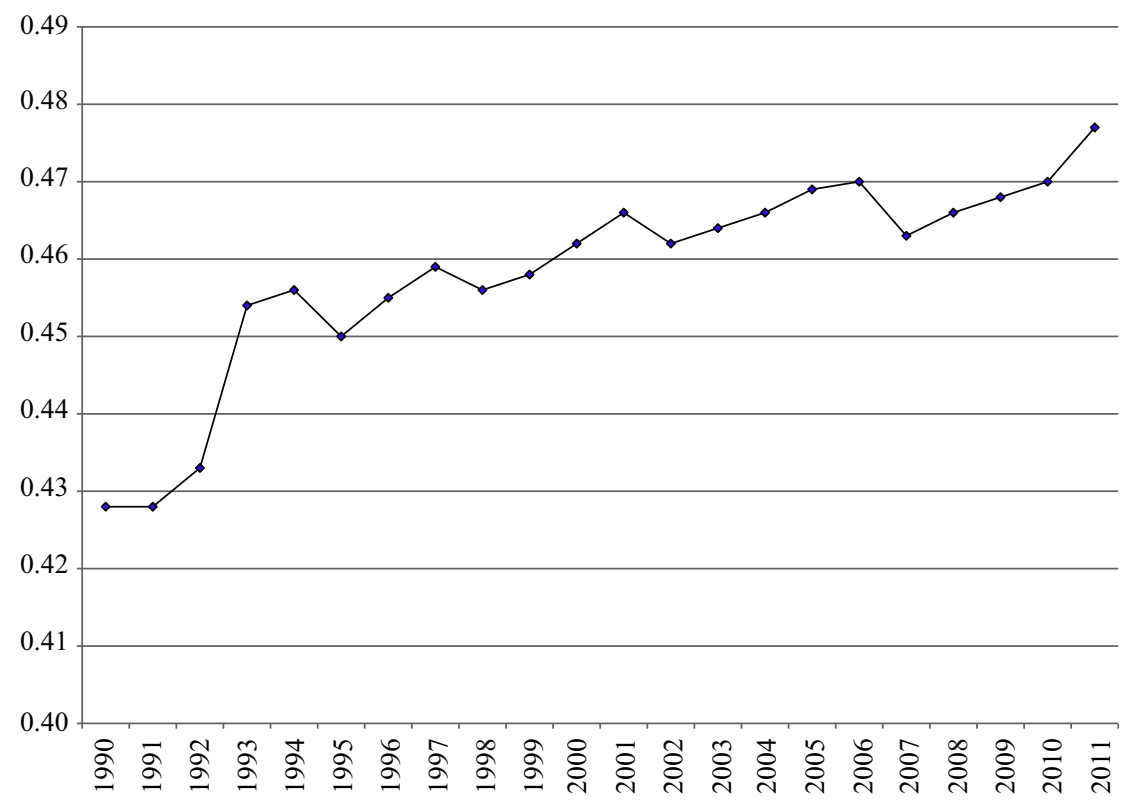

Source: Census Bureau.

\section{Figure 11 Gini coefficient}

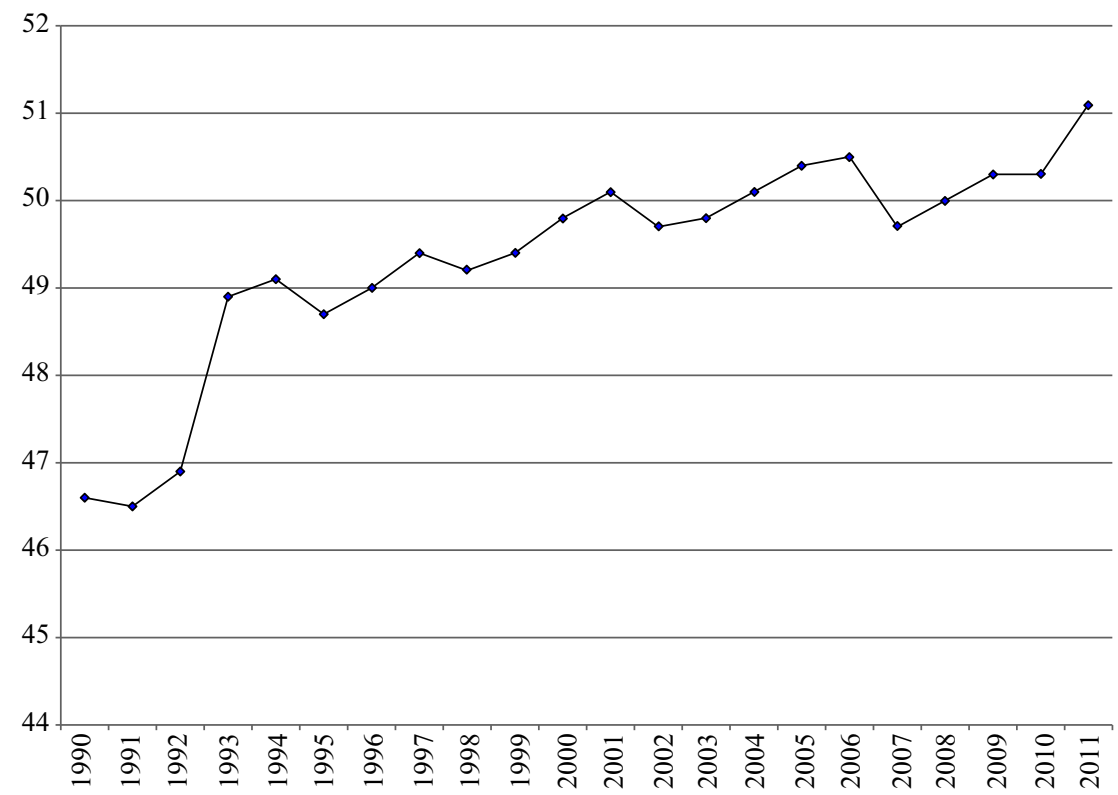

Source: Census Bureau.

\section{Figure 12 Top quintile income share}




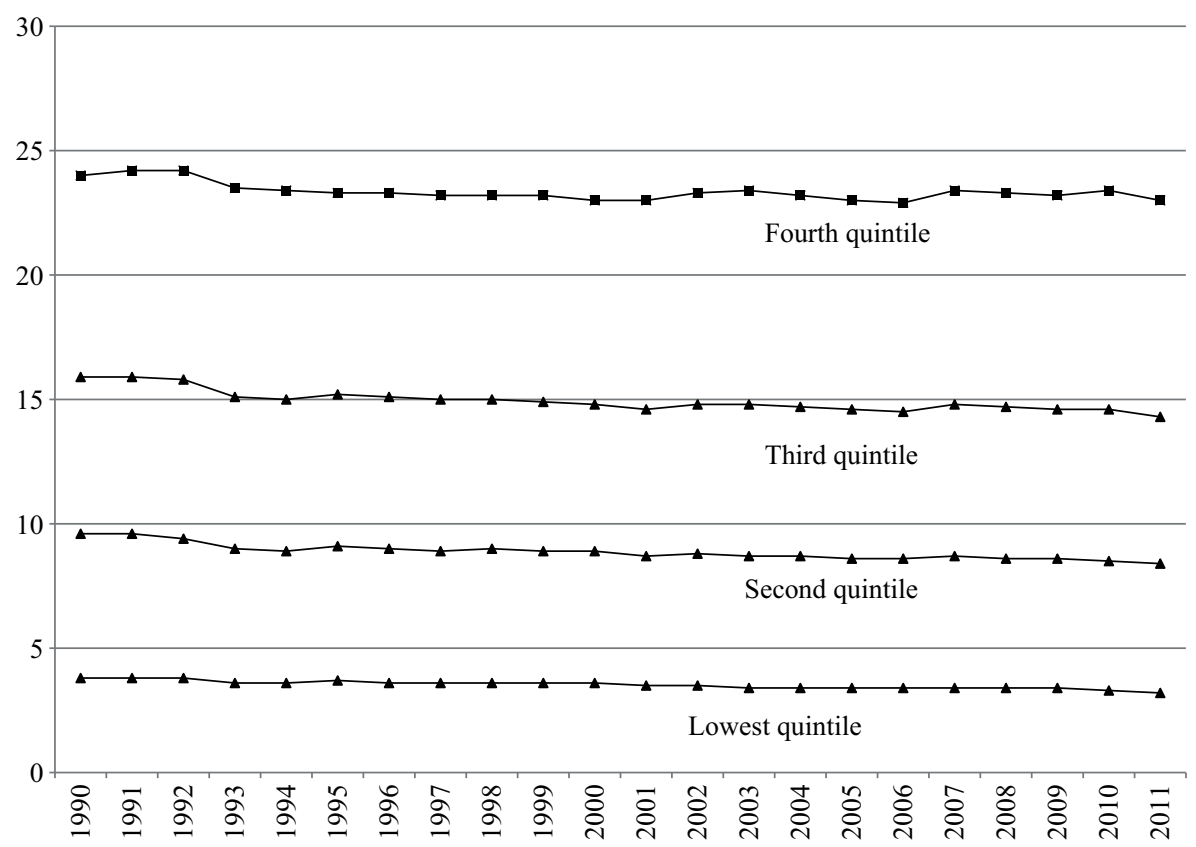

Source: Census Bureau.

\section{Figure 13 Income shares by quintiles}

increased during the period, mitigating the overall loss for the top 10 percent (Piketty and Saez 2006, updated figures). Between 2007 and 2011, the income share of the top 1 percent, including capital gains, decreased almost 4 percent, going from 23.50 percent to 19.82 percent, while the share of the top 10 percent only decreased about 1.5 percent, going from 49.74 percent to 48.20 percent. Overall, the income share decrease of the top 1 percent was redistributed within the top 20 percent and largely for the top 90-99 percent.

Overall, inequality indices show slight improvement immediately after the crisis. This is most likely due to the decline in the market values of financial assets and the corresponding decline in their income streams. However, soon after, inequality began to trend upwards again, indicating that the net effect of the financial crisis has been to increase inequality. ${ }^{6}$ On the other hand, poverty rates after the crisis have shown an unequivocal increase.

\subsection{Poverty}

While inequality fluctuated, poverty unequivocally increased as a result of the crisis. The rate of people living below the poverty line, as measured by the US census,

6. There have also been changes in the wealth inequality (Pfeffer et al. 2013; Wolff 2013). For example, between 2007 and 2011 about one-fourth of families lost more than 75 percent of their wealth and about half lost more than 25 percent of their wealth. According to Pfeffer et al. (2013, p. 650), 'multivariate longitudinal analyses document that these large relative losses were disproportionally concentrated among lower-income, less educated and minority households.' 


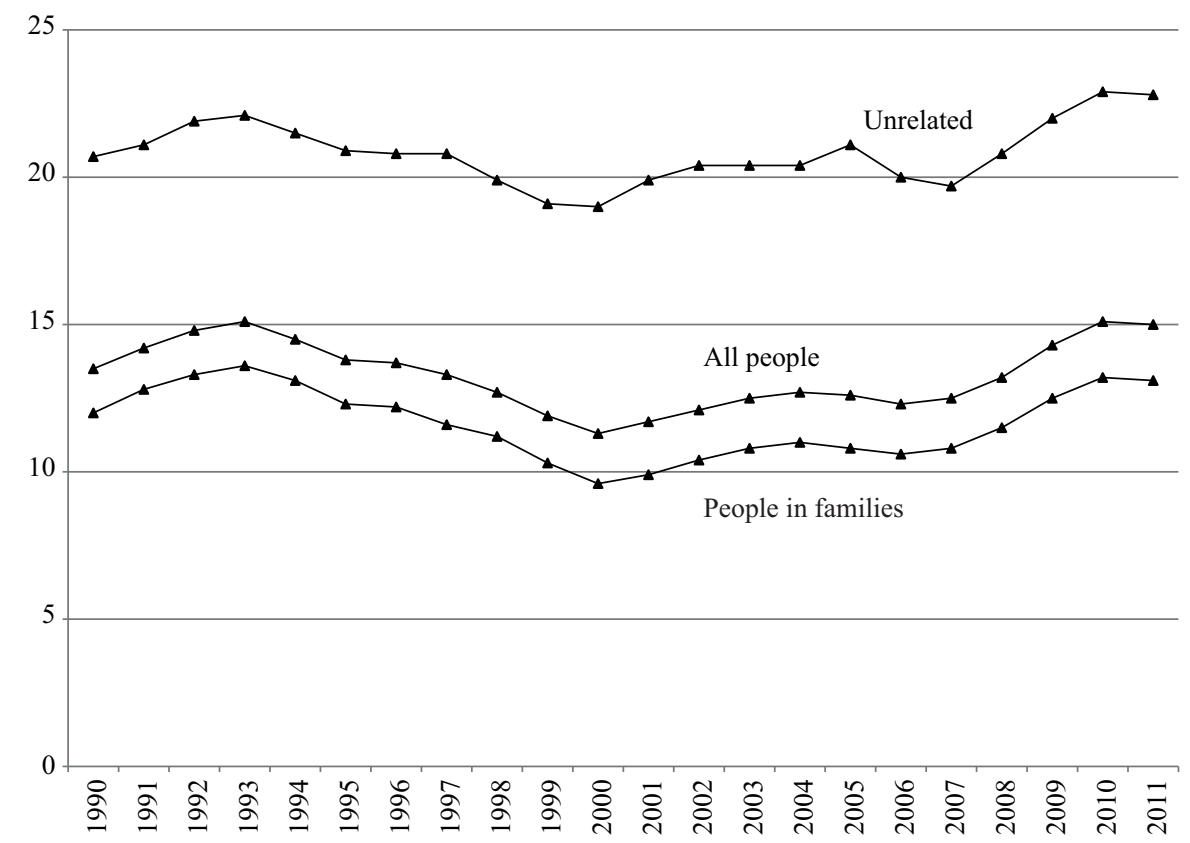

Source: Census Bureau.

\section{Figure 14 Poverty rates}

increased from 12.5 percent in 2007 to 15 percent in 2011, offsetting all the progress made on that front since the 1990s (Figure 14). Data from the US Census bureau also indicates that many households slid downward in terms of income. Between 2007 and 2011, the proportion of households earning less than \$15000 increased from 11.9 percent to 13.5 percent and the proportion earning between $\$ 15000$ and $\$ 24999$ went from 11 percent to 11.5 percent (DeNavas-Walt et al. 2012). The largest decreases happened in the \$75 000-\$99 999 and \$100 000-\$149 999 brackets.

\section{CRISIS AND GOVERNMENT POLICIES}

Financial crises in low- and middle-income countries were used as opportunities to further the neoliberal agenda of deregulatory policies as well as to open up these economies to international capital. Government budgets were oriented towards generating a primary surplus in accordance with IMF structural adjustment programs, and cuts in social expenditures were common (Dufour and Orhangazi 2007; 2009). The US did not face any such external constraint and introduced the Troubled Asset Relief Program (TARP) in order to help the financial sector. In the process, a large number of banks as well as financial institutions such as Fannie, Freddie, and AIG received direct support from the government. While the financial sector was clearly prioritized, around $\$ 3$ trillion in government subsidies was allocated to buy toxic financial assets and recapitalize insolvent financial institutions (Tcherneva 2012, p. 4). Furthermore, immediately after the crisis, a stimulus package of $\$ 152$ billion in tax rebates for 
2008 was passed, to be followed by a package in 2009 of $\$ 787$ billion. In addition, the FED took actions well beyond its past role and supported not only banks but also all types of other financial institutions and some non-financial corporations through its liquidity provision and asset purchase programs.

Public debt significantly increased following the crisis, showing that the government shouldered a significant part of the burden. Figure 15 presents federal government total debt as a percentage of GDP. In terms of government spending, income security spending - consisting largely of unemployment benefits, retirement benefits, disability payments, and welfare and social services payments - went up early on, but has since been coming down. Nonetheless, it is still above precrisis levels, and so are social expenditures, despite a slow decline recently (Figure 16). These trends differ from what was observed during most developing-country crisis experiences. One reason behind this is that benefits such as unemployment benefits are much more established in the US and the automatic stabilizers kick in when there is a slowdown. A second reason is that the US did not have to follow an IMF structural adjustment program forcing them to cut social expenditures. ${ }^{7}$ Third, the US

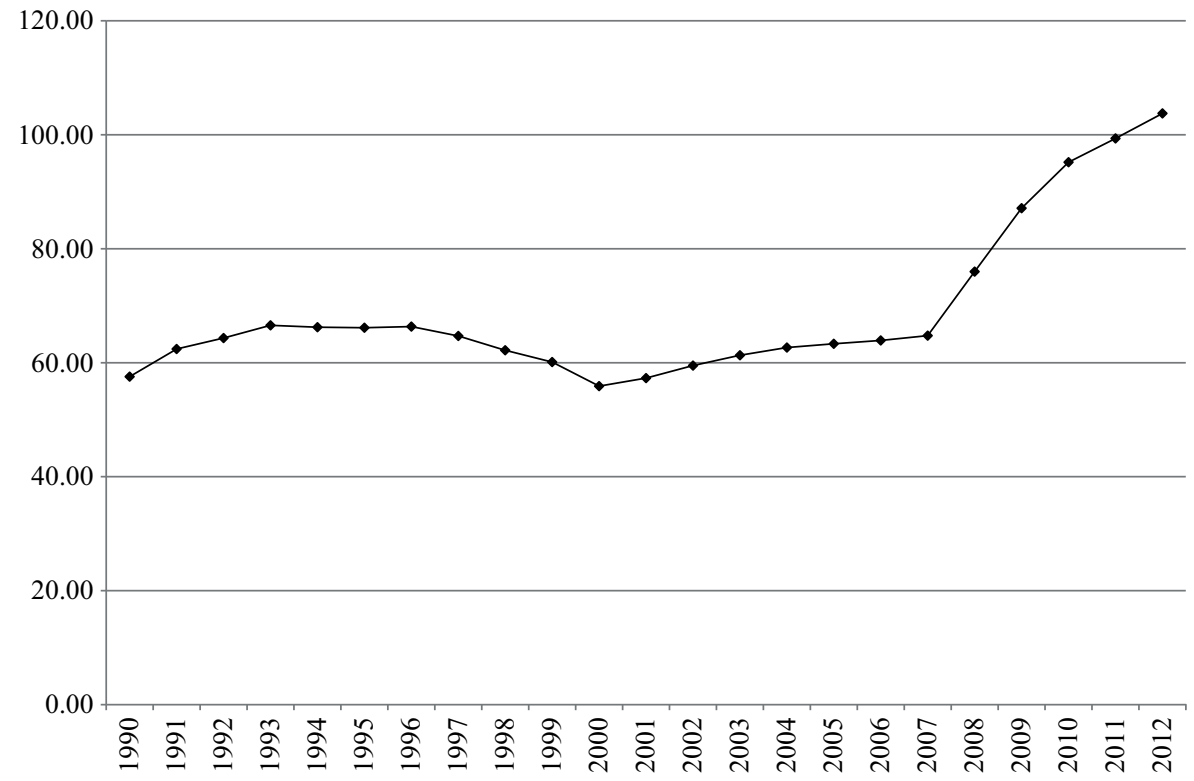

Source: Bureau of Economic Analysis.

Figure 15 Total federal debt as a percentage of GDP

7. Moffitt (2013, p. 143) finds that 'aggregate per capita expenditures in safety net programs grew significantly, with particular strong growth in the SNAP, EITC, UI, and Medicaid programs.' However, state and local governments, in many cases, had to make dramatic reductions in their spending as their tax incomes fell. For example, in the case of higher education, Barr and Turner (2013) find that despite federal aid policies becoming more generous, the decline in state budget allocations had a negative effect on colleges and universities in maintaining programming and accommodating student demand. 
168 Review of Keynesian Economics, Vol. 4 No. 2

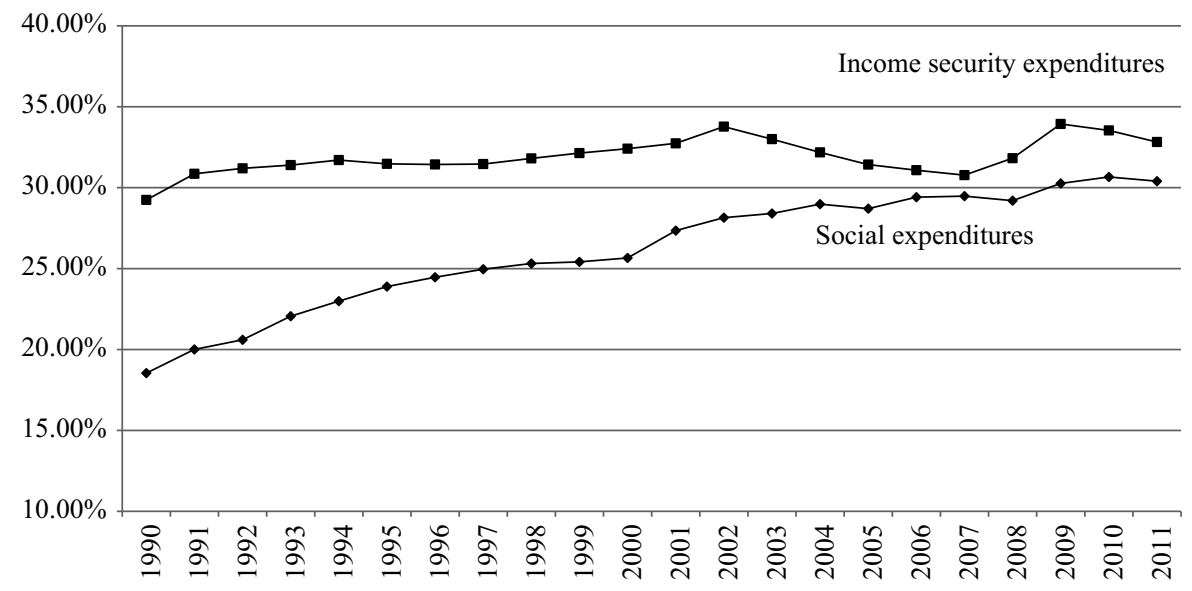

Source: Bureau of Economic Analysis.

Figure 16 Social and income security expenditures as a percentage of government current expenditures

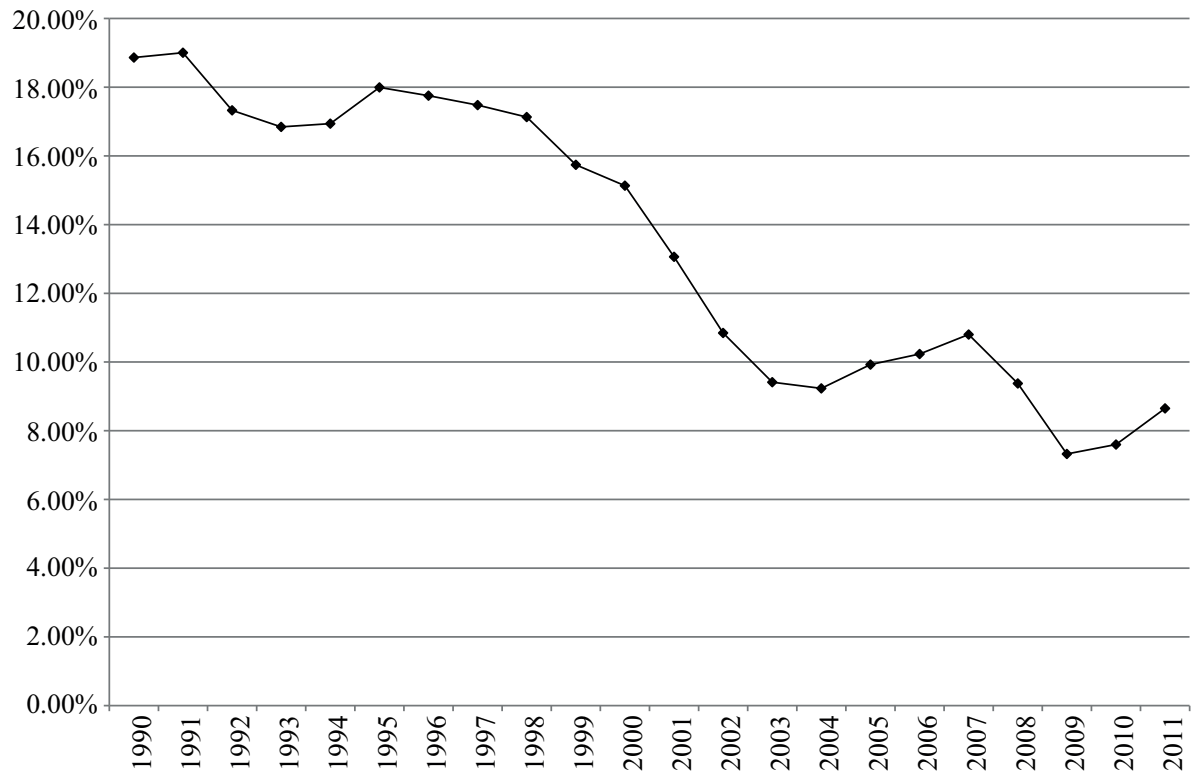

Source: Bureau of Economic Analysis.

Figure 17 Interest payments as a percentage of government current expenditures

government, despite the crisis, can borrow at low interest rates, which gives it much more room than governments in developing countries. In fact, as can be observed in Figure 17, interest payments as a percentage of current expenditures remained fairly low throughout the crisis as well as afterwards. Similarly, by looking at public debt 


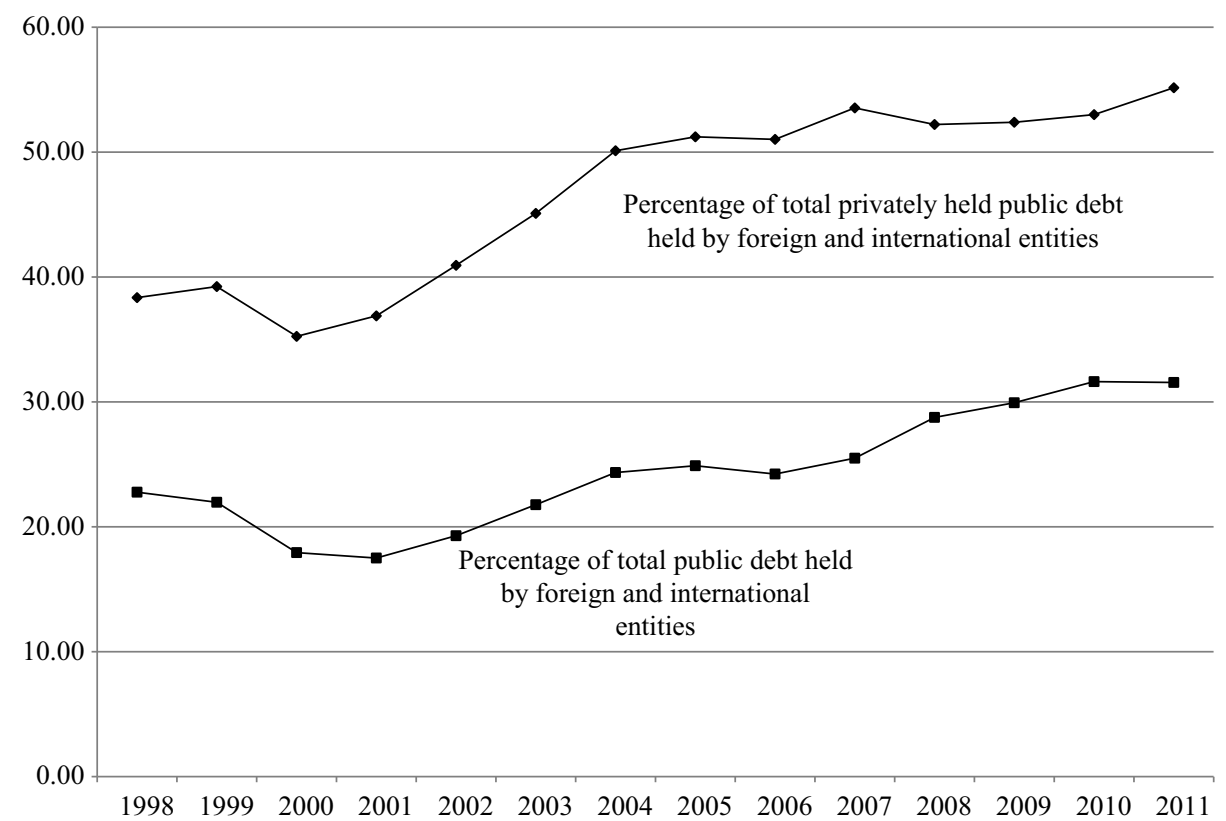

Source: FRED.

\section{Figure 18 Public debt held by foreign entities}

held by foreign and international lenders, it can be seen that even during and after the crisis the US government was able to borrow from abroad because the dollar still serves as the reserve currency and there is a high level of instability in other parts of the world, especially in the eurozone (Figure 18). This is also indicative of another key difference: the US government borrows in its own currency. Consequently, short of choosing to do so willingly, it cannot default, unlike developing countries who have to find sources of foreign exchange to service their foreign debts. Incidentally, while developing countries typically devote a great deal of resources to reserve accumulation after a crisis, a precautionary cost to ward off possible future crises (Dufour and Orhangazi 2007; 2009), the US does not have to do this so long as the dollar remains a reserve currency. This is yet another way in which the US government has greater room for maneuver than its counterparts in developing countries. ${ }^{8}$

8. However, this is not to say that the US government was not subject to similar pressures. Increasing budget deficits, together with the prospective long-term financial problems of Social Security and Medicare programs triggered a debate in the US on the need for fiscal austerity. In Crotty's (2012, p. 79) words, 'a coalition of the richest and most economically powerful segments of society, conservative politicians who represent their interests and rightwing populist groups like the Tea Party has demanded that deficits be eliminated by severe cuts at all levels of government in spending that either supports the poor and the middle class or funds crucial public investment. It also demands tax cuts for the rich and for business.' 


\section{CRISIS AND CAPITAL INFLOWS}

Some of the processes at work during and after financial crises in less-developed countries had an air of neo-colonialism (Crotty and Lee 2001; Harvey 2003; Duménil and Lévy 2006; Dufour and Orhangazi 2007; 2009). Many of the countries beset by crises were pressured to liberalize their markets or leave them open during the downturn, leading to a transfer of assets to international finance capital and other foreign capitalists who are well-positioned to acquire otherwise profitable assets negatively affected by the crisis. In this way, for example, a good share of the Turkish banking system was taken over by foreign banks following a financial crisis that occurred in 2000-2001 (Dufour and Orhangazi 2009). More generally, capital inflows increased markedly during and right after financial crises, followed by an increase in the level of profits repatriated abroad a few years down the road.

The reality faced by a country like the US is evidently different, as there are not really any international institutions or other countries able to dictate policies to its government. Nonetheless, there has been a marked increase in international capital movements during the current crisis, suggesting that some capitalists were well-positioned to seize opportunities as they presented themselves. Inward foreign direct investment (FDI) flows peaked at the beginning of the crisis and remained relatively high thereafter, while outward FDI reached new heights during the same period (Figure 19). The inward FDI is largely made up of mergers and acquisitions, with the vast majority of the capital coming from developed countries (Europe, Canada, and Japan), with a couple of notable exceptions like the purchase of 4.9 percent of Citigroup by the

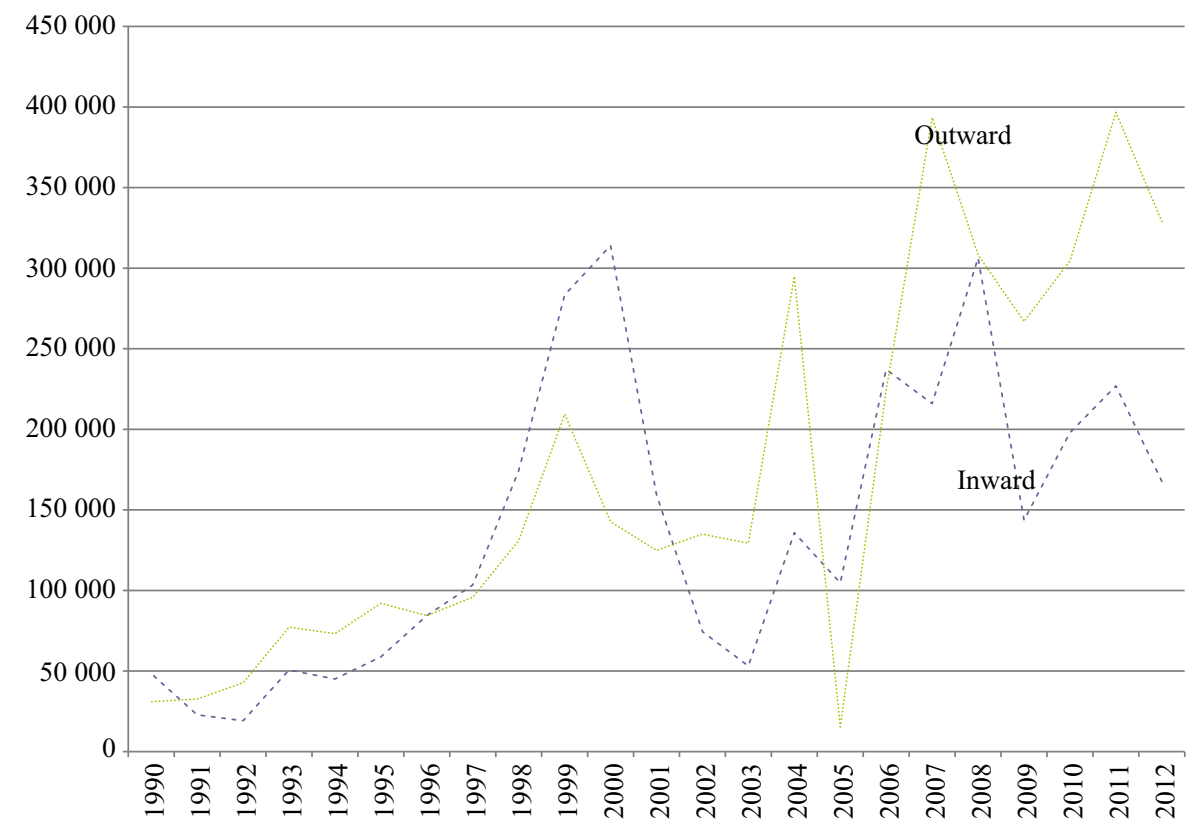

Source: UNCTAD.

Figure 19 Foreign direct investment (millions of current dollars) 


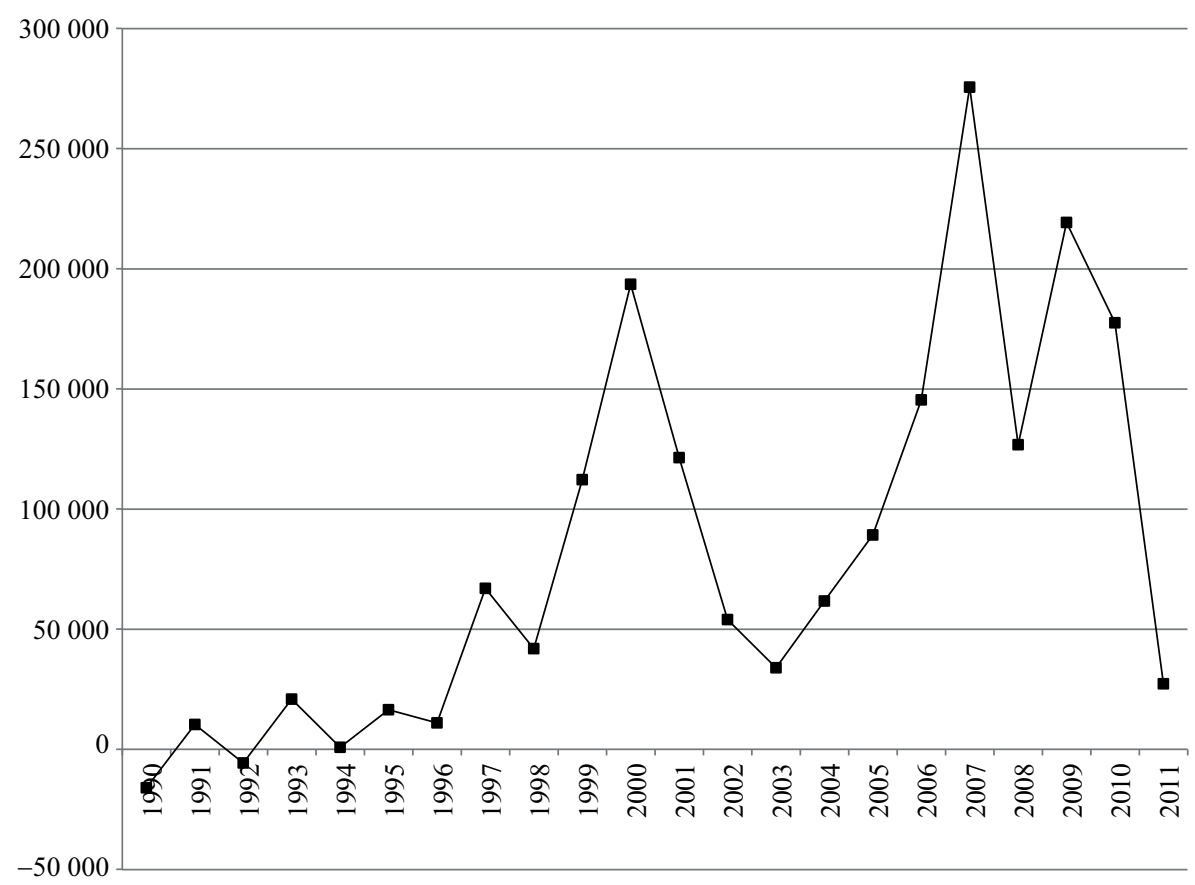

Source: World Bank.

Figure 20 Portfolio equity inflows (millions of current dollars)

investment authority of the United Arab Emirates in 2008 (Kornecki 2013). Moreover, as inward FDI peaked in 2008, in the middle of the financial turmoil, the largest recipient of that FDI was finance, with 31.1 percent of the total, with depository institutions getting a further 8.1 percent (ibid.). This suggests that this FDI was in large part targeted at grabbing financial assets while the US financial industry was shaken and moving in to get a share of the market. Portfolio equity inflows were also high during this period, peaking in 2007 and only coming down in 2011 (Figure 20). These recent inflows have contributed to a secular rising trend in foreign ownership of equity in the US, which now stands at around 10 percent of the total (Walker 2013).

The instability inherent in the crisis is the source of another financial transfer to countries with strong currencies: other countries trying to ward off that instability accumulate reserves, which represents seigniorage for the countries emitting reserve currencies. While the relative importance of the US dollar as a reserve currency has declined over the last decade, over 60 percent of the official reserves for which the currency composition is reported (over 55 percent in 2012) was still denominated in US dollars in 2012 (IMF, COFER database). Between 2007 and 2012 alone, there was an increase of over $\$ 1$ trillion in the official reserves known to be held in dollars, going from $\$ 2642$ billion to $\$ 3764$ billion (ibid.).

In short, while developing economies are weaker and more vulnerable after financial crises, in the case of the US, international capital flows seem to have supported segments of the US economy as a result of the unique role of the US dollar in the world economy. 


\section{CONCLUDING REMARKS}

In this paper, we examined the experience of the US economy in the aftermath of the 2007-2008 financial crisis in terms of the questions and issues typically raised in studies of low- and middle- income countries. We analysed the consequences of the 2007-2008 financial crisis on different groups in the US, by looking at how the burden was shared, who suffered and by how much, and who profited. This follows a literature that developed in the wake of the increase in instability following the end of the Bretton Woods system and the advent of neoliberal economic policies. Most of this literature is concerned with financial crises in low- and middle-income countries, where instability had largely been contained prior to the 2007-2008 crisis.

The literature on the effects of the financial crises in low- and middle-income countries has three broad findings. First, the burden of the crises falls disproportionately on labor while capital as a whole quickly recovers. Unemployment increases, real wages and labor share of income decline as inequality and poverty rise. Second, government policies in the aftermath of financial crises favor capital, particularly financial capital at the expense of cuts for broader segments of the society. Third, international capital takes advantage of the financial crises by acquiring financial and non-financial assets at fire-sale prices.

Our findings suggest that some of patterns present in previous financial crises in low- and middle-income countries are also visible in the US. The burden of the crisis fell disproportionately on labor and the poorer segments of society and the power of the labor movement was further eroded, while capital recovered rapidly overall. What is more, some segments of capital were in fact able to gain from the situation. These results are in line with previous experiences. One major difference, though, is that the US government does not face the same constraints as its counterparts in lowand middle-income countries, both in terms of its ability to finance its activities and the leeway it has regarding policy-making. Consequently, financing costs did not rise dramatically even as the public debt did and public spending was relatively more stable than what was observed in previous financial crises.

This last result is not trivial. The fact that labor and poorer segments of society were disproportionately hit in the crisis and helped relatively less in the recovery, despite the margin of maneuver available to the government, suggests that there are common elements in the dynamics of financial crises across the globe. Regardless of the position of the country in the global economy or the means of intervention of the government, crises typically result in a redistribution towards capital in general and the wealthiest segments of the society in particular. This is generally consistent with the argument that capitalism's institutional structure and the government policies together ensure that capital and the wealthy come out of the crisis ahead. This then poses a quandary: is it that these results represent the immanent logic of the system, which the state is relatively powerless to affect, or that the current policy consensus is what generates them? Further research on the mechanisms at work is needed to answer this question and delineate more precisely how such outcomes are brought about, but already the situations of some governments, notably in Europe, which have promised a different outcome, provide a natural experiment.

In the US, it remains to be seen whether a durable recovery can be obtained from the outcomes we outline above. In many ways, the crisis exacerbated some of the existing contradictions of the neoliberal era and government intervention did not do much to alleviate these problems. Stagnant wages, for example, imply a shaky consumption base for years to come. Low- and middle-income countries don't offer a 
precise image of what could come to pass either, as medium-run outcomes differ. While there are important similarities in crisis dynamics, the shape of the ensuing recovery (or lack thereof) has a lot to do with idiosyncratic development paths, typically with higher involvement from international finance capital. As the US is less constrained than these countries in that regard, it is hard to draw lessons from their experience, beyond the fact that the position of finance capital has once again been bolstered.

\section{ACKNOWLEDGEMENTS}

The authors thank Onur Özdemir for research assistance and the two anonymous referees for their comments on an earlier version of this paper. Özgür Orhangazi acknowledges research funding support from a Marie Curie European Reintegration Grant within the 7th European Community Framework Programme (grant no FP7-PEOPLE-2011-CIG: 303981). Mathieu Dufour thanks the Scientific and Technological Research Council of Turkey (TÜBITTAK) for a travel grant through the 2221 Visiting Scientists Fellowship Programme that partly made this joint research possible.

\section{REFERENCES}

Arestis, P., A. Charles, and G. Fontana. 2013. 'Financialization, the Great Recession, and the stratification of the US labor market,' Feminist Economics, DOI:10.1080/13545701.2013.795654.

Barr, A. and S.E. Turner. 2013. 'Expanding enrollments and contracting state budgets: the effect of the Great Recession on higher education,' Annals, AAPSS, 650.

Crotty, J. 2012. 'The great austerity war: what caused the US deficits crisis and who should pay to fix it?' Cambridge Journal of Economics, 36(1): 79-104.

Crotty, J. and K. Lee. 2001. 'Korea's neoliberal restructuring: miracle or disaster,' Dollars and Sense, 236, 28.

DeNavas-Walt, C., B.D. Proctor, and J.C. Smith. 2012. 'Income, poverty, and health insurance coverage in the United States: 2011,' Census Bureau, Current Population Reports.

Diwan, I. 2000. 'Labor shares and globalization,' World Bank, Washington, DC.

Diwan, I. 2001. 'Debt as sweat: labor, financial crises, and the globalization of capital,' World Bank, Washington, DC.

Dufour, M. and O. Orhangazi. 2007. 'International financial crises: scourge or blessing in disguise,' Review of Radical Political Economics, 39(3): 342-350.

Dufour, M. and O. Orhangazi. 2009. 'The 2000-01 financial crisis in Turkey: a crisis for whom?' Review of Political Economy, 21(1): 101-122.

Duménil, G. and D. Lévy. 2006. Imperialism in the neoliberal era: Argentina's reprieve and crisis, Review of Radical Political Economics, 38(3): 388-396.

Duménil, G. and D. Lévy. 2011. The Crisis of Neoliberalism, Cambridge, MA: Harvard University Press.

Dymski, G., J. Hernandez, and L. Mohanty. 2013. 'Race, gender, power, and the US subprime mortgage and foreclosure crisis: a meso analysis,' Feminist Economics, DOI:10.1080/ 13545701.2013.791401.

Eichengreen, B. 2001. Financial Crises and What to Do about Them, Oxford: Oxford University Press.

Feldstein, M. 2008. 'Did wages reflect growth in productivity?' Journal of Policy Modelling, 30: 591-594.

Harvey, D. 2003. The New Imperialism, Oxford: Oxford University Press.

Jayadev, A. 2005. 'Capital account liberalization, growth and the labor share of income,' in: G. Epstein (ed.), Capital Flight and Capital Controls in Developing Countries, Cheltenham, UK and Northampton, MA: Edward Elgar, pp. 15-57. 
174 Review of Keynesian Economics, Vol. 4 No. 2

Kornecki, L. 2013. 'Inward FDI in the US and its policy context,' Vale Columbia Center on Sustainable International Investment.

Mishel, L. 2012. 'The wedges between productivity and median compensation growth,' Economic Policy Institute, Issue Brief 330.

Mishel, L. and N. Finio. 2013. 'Earnings of the top 1.0\% rebound strongly in the recovery,' Economic Policy Institute, Issue Brief 347.

Mishel, L. and K. Gee. 2012. 'Why aren't workers benefiting from labor productivity growth in the United States?' International Productivity Monitor, 23: 31-43.

Mishel, L. and N. Sabadish. 2002. 'Methodology for measuring CEO compensation and the ratio of CEO-to-worker compensation,' Economic Policy Institute, Working Paper 293.

Mishel, L., J. Bivens, E. Gould, and H. Shierholz. 2012. The State of Working America. Ithaca, NY: Cornell University Press.

Moffitt, R.A. 2013. 'The Great Recession and the social safety net,' Annals, AAPSS, 650.

National Employment Law Project. 2012. Data Brief 2012: The Low-Wage Recovery and Growing Inequality.

Oleinik, A. 2013. 'The 2008 financial crisis through the lens of power relationships,' Journal of Economics Issues, XLVII(2): 465-473.

Onaran, O. 2007. 'Wage share, globalization, and crisis: the case of the manufacturing industry in Korea, Mexico, and Turkey,' International Review of Applied Economics, 23(2): 113-134.

Orhangazi, Ö. 2008. Financialization and the U.S. Economy, Cheltenham, UK and Northampton, MA: Edward Elgar.

Orhangazi, Ö. 2011. "Financial" vs. "Real": an overview of the contradictory role and place of finance in the modern economy,' Research in Political Economy, 27, 121-148.

Pessoa, J.P. and J. Van Reenen. 2012. 'Decoupling of wage growth and productivity growth? Myth and reality,' Resolution Foundation: Commission on Living Standards.

Peterson, J. 2012. 'The Great Crisis and the significance of gender in the US economy,' Journal of Economics Issues, XLVI(2): 277-290.

Pfeffer, F.T., S. Danziger, and R.F. Schoeni. 2013. 'Wealth disparities before and after the Great Recession,' Annals, AAPSS, 650.

Piketty, T. and E. Saez. 2006. 'The evolution of top incomes: a historical and international perspective,' NBER Working Papers 11955, National Bureau of Economic Research.

Reinhart, C.M. and K.S. Rogoff. 2011. This Time is Different: Eight Centuries of Financial Folly. Princeton, NJ: Princeton University Press.

Tcherneva, P.R. 2012. 'Reorienting fiscal policy after the Great Recession,' Levy Institute Working Paper 719.

Wade, R. and F. Veneroso. 1998. 'The Asian crisis: the high debt model vs. the Wall StreetTreasury-IMF complex,' New Left Review, I(228), 3-23.

Walker, D. 2013. 'Quarterly update: foreign ownership of US assets,' Center for Geoeconomic Studies.

Wolff, E.N. 2013. 'The asset price meltdown, rising leverage, and the wealth of the middle class,' Journal of Economics Issues, XLVII(2): 333-342. 